\title{
A MORTE COMO HIGIENIZAÇÃO SOCIAL/SEXUAL NA OBRA DE NELSON RODRIGUES: UMA LEITURA DE GÊNERO, SEXUALIDADE E MASCULINIDADES
}

\author{
Death as social/sexual hygiene in Nelson Rodrigues' work: a reading of gender, \\ sexuality and masculinities
}

Paulo Valente

(iD) https://orcid.org/0000-0002-2223-8146

Universidade Federal de Santa Catarina, Programa de Pós-Graduação em Literatura, Florianópolis, SC, Brasil. 88040-900 - ppglitufsc@gmail.com

Resumo: Este artigo pretende revisitar o conto-crônica "Delicado", do dramaturgo e jornalista Nelson Falcão Rodrigues (1994), presente na coletânea $A$ vida como ela é..., fruto de seu trabalho para o jornal Última Hora, a fim de discutir de que modo a narração evidencia uma sociedade heteronormativa compulsória a qual violenta a existência do protagonista alheio à norma, a ponto de este vir a provocar a própria morte, não suportando a pressão externa para cumprir o seu 'papel de homem'. Ao longo da escrita, evidenciamos como Eusebiozinho, personagem principal, ao romper com o binarismo sexual e norma social, é obrigado a retornar a um suposto lugar original/apriorístico, o da masculinidade hegemônica, por via da heterossexualidade compulsória, imposta pela família e representada pela figura do tio. Recorremos, para tanto, aos estudos queer e aos textos de Adrienne Rich (2003), Judith Butler (2005), Monique Witting (1992), Teresa de Lauretis (1994), Robert Connell (1995) e Michael Foucault (2001), dentre outros.

Palavras-chave: "Delicado". Heterossexualidade compulsória. Masculinidades.

Abstract: This article aims to revisit the short story "Delicado", by the playwright and journalist Nelson Falcão Rodrigues (1994), present in the collection $A$ vida como ela é..., the result of his work for the newspaper Última Hora, in order to discuss how the narration shows a compulsory heteronormative society that violates the existence of the protagonist outside the norm, to the point that he comes to cause his own death, not supporting external pressure to fulfill his 'role as a man'. Throughout the writing, we show how Eusebiozinho, the main character, when breaking with sexual binarism and social norm, is obliged to return to a supposed original / aprioristic place, mandatory masculinity, through compulsory heterosexuality, imposed by the family and represented by the figure of his uncle. For that, we used queer studies and texts by Adrienne Rich (2003), Judith Butler (2005), Monique Witting

Esta obra está licenciada sob uma Creative Commons - Atribuição 4.0 
(1992), Teresa de Lauretis (1994), Robert Connell (1995) and Michael Foucault (2001), among others.

Keywords: "Delicado". Compulsory heterosexuality. Masculinities.

SELMINHA - Uma coisa que me dá vontade de morrer. Como é que um homem pode desejar outro homem!

Nelson Rodrigues (2004), O beijo no asfalto

\section{Introdução}

Neste artigo, pretendemos retomar o texto de Nelson Rodrigues (1994), "Delicado", presente na obra $A$ vida como ela é..., a fim de aprofundar a discussão a respeito dos modos como a Literatura pauta uma sociedade em que a heterossexualidade compulsória se mostra como regra, e a homossexualidade como tabu. Por heterossexualidade compulsória, compreendemos o que Adriene Rich postula no começo dos anos 1980, a saber uma matriz de comportamentos e desejos heterossexuais, os quais somos compelidos a assumir em uma sociedade binária, como se fosse inato/natural. Dessa forma, produz-se e se legitima uma hierarquia e assimetria de poder, segundo o qual alguns corpos estão determinados a assumir determinados papeis sociais e são superiores em relação a outros.

Ocorre, indubitavelmente, o que poderíamos chamar de uma heterossexualização do desejo gerando efeitos simbólicos daquilo que socialmente associamos ao feminino e ao masculino. Nessa seara, regulariza-se o feminino como subjugado, diminuído nessa economia binária dos corpos, cabendo-lhe um papel menor, frágil, dócil, obediente e, ao mesmo tempo em que desejável no campo da atração sexual, abominável em sua aparência e práticas.

Nesse cenário que se postula, nascer homem (leia-se, aqui, com pênis) e não idealizar as práticas masculinas pode soar uma ameaça ao status quo, representando um corpo/sujeito abominável e não tolerável, o qual deve ser controlado e compelido a performar códigos sociais da masculinidade. O protagonista do conto que ora lemos ousa romper esse binarismo e norma social e, tal qual alguém perdido, fora da norma, precisa ser reconduzido ao lugar que lhe é de direito - mas também dever -, o da masculinidade hegemônica, por via da heterossexualidade compulsória, conforme discutiremos com mais atenção no decorrer deste trabalho.

Nossa leitura privilegia, portanto, um olhar sobre a sexualidade de Eusebiozinho, protagonista de "O delicado", posta no limiar do conflito entre o desejo/vontade e a norma social. Em certa medida, em função de sua sexualidade naquele contexto carioca suburbano em que se passa a história do conto-crônica, ser feminino significa um desvio tamanho que lhe restava como identidade a anormalidade (FOUCAULT, 2001). E ser anormal é ser errado, desviante, ter a sua identidade negada.

Entendemos, pois, a sexualidade como meio de expressão da identidade dos sujeitos e, portanto, como uma construção discursiva que legitima certas práticas e torna-as naturais, como é o caso da heterossexualidade, em oposição a outras, deslegitimadas e subjugadas, como a homossexual, que precisa ser controlada por agentes representativos desse poder, os quais negam a existência do outro em função de seus corpos, desejos e experiências. 
Assim, lemos, pois, a identidade e a sexualidade que Eusebiozinho idealiza: alheia à normalidade dos discursos hegemônicos heterossexual e masculino, logo passivo a punições uma vez que transgride a leis que regulamentam o comportamento e a existência da própria sociedade binária. Em outros termos, em uma sociedade em que a heterossexualidade se constitui como a marca da normalidade, discurso a ser reverberado, defendido e difundido, qualquer prática - ou suspeita de prática - que fuja à regra, à norma, deve ser combatida, deslegitimada, sendo o sujeito que as pratica reintegrado ao seio de uma sociedade normal leia-se heterossexual - ou, simplesmente, excluído, morto, em nome de uma higiene social e sexual.

Para tanto, a defesa da heterossexualidade como desejo e comportamento normais trabalha na ordem dos corpos disciplinados a reproduzir uma lógica binária que regulamenta a existência a parir de dispositivos coercitivos que a protegem, e regulam-na. No texto literário que ora tratamos de ler, esses dispositivos são retomados continuamente na figura masculina do tio do protagonista que deve, primeiramente, perceber a 'desordem' em que se encontra o garoto com trejeitos femininos para, em seguida, como um guardião da heterossexualidade, guiá-lo de volta à normalidade, exigindo um matrimônio com uma moça. Importante destacar desde já que seja uma figura masculina que performatiza o ideal da virilidade e da masculinidade quem interfere na narrativa, a fim de levar o sobrinho a ter 'jeito de homem'.

Por fim, cabe ao protagonista apenas dois caminhos, ou rende-se à lógica da normalidade monogâmica heterossexual e se casa ou evade-se dela. Opta pela segunda e comete suicídio deixando de existir naquela sociedade na qual, de fato, nunca pôde existir, pelo menos, não como era, não com sua identidade e sexualidade. O casamento obrigatório surge, nesse contexto como uma força de controle social e manutenção da ordem heterossexual institucionalizada, como define Adrienne Rich (2003).

Empreendemos uma discussão do conto-crônica que apesente como a heterossexualidade compulsória tenta aprisionar, além dos corpos, a mente, a sexualidade e as experiências sociais, em um regime que impõe uma única realidade possível, desviando o olhar daquilo que fuja a uma norma imposta, a uma narrativa prescrita, na qual nos cabem papeis muito bem definidos dos quais não podemos fugir, nem em pensamento. E como, quando há um desvio, a sociedade reage a ponto de tornar esse ser desviante um pária, alguém que deve ter a sua existência sublimada, esquecida, apagada ou, até mesmo, exterminada.

Para tanto, propomos a divisão do artigo em três momentos distintos: 1) retomada sucinta da obra de Nelson Rodrigues; 2) discussão dos textos de Adrienne Rich (2003), Judith Butler (2015), Monique Wittig (1992), dentre outras teóricas a fim de debater a formação da identidade masculina; 3 ) a leitura do conto, propriamente dita.

\section{Nelson Rodrigues e $A$ vida como ela é...}

Nelson Rodrigues é um dos autores com obra mais extensa do século XX. O anjo pornográfico, epíteto pelo qual era conhecido e ficou imortalizado na biografia de Ruy Castro, produziu para o teatro obras até hoje remontadas e adaptadas aos mais diversos formatos no 
cinema e na televisão, e também produziu em prosa, por aproximadamente dez anos no jornal Última Hora.

A vida como ela é... nasceu como coluna diária cuja função seria abordar assuntos já discutidos em outras colunas do periódico Última Hora. Assim, a sua produção em prosa diária deveria refletir ou se pautar em algum tema factual marcante daquela edição do periódico. Após algumas poucas edições, Nelson Rodrigues passou a produzir histórias fictícias, quase sempre ambientadas no subúrbio carioca, fruto de sua aguda e perspicaz observação cotidiana. Suas narrativas sempre privilegiaram temas tabus na sociedade àquela época e que ainda permanecem pouco comentados. Seus narradores contam histórias de adultérios, prostituição, homossexualidade e desvendam a hipocrisia social para com tais temáticas. "Delicado", corpus dessa análise, narra a história de um garoto, filho caçula criado por sua mãe e irmãs mais velhas. Em determinado momento da narrativa, um tio os visita e repreende o modo como o sobrinho está sendo criado, determinando que o garoto comece a namorar urgentemente para vir a ter 'jeito de homem'.

Importante destacar que, na visão repressora do tio, uma vez que Eusebiozinho biologicamente era homem deveria performatizar signos da masculinidade, dentre os quais constaria, certamente, o desejo pelo sexo oposto. Em outras palavras, o tio - representante da sociedade binária - quer controlar a própria existência do sobrinho.

Cabem, aqui, algumas interrogações: O que significa ter ‘jeito de homem'? Quem determina? Como o faz? O jeito de homem é algo encenado ou empírico? Como a sociedade repreende e adéqua os seres masculinos para terem ‘jeito de homem'? 'Ser homem' coincide com masculinidade? Ser criado por mulheres fere esse processo?

Essas são algumas das diversas questões impostas ao leitor do conto. Obviamente, não pretendemos no curto espaço de um artigo dar conta de responder a todas, mas objetivamos discutir o modo como a sociedade, aqui ficcionalizada por Rodrigues, produz uma narrativa sexual/identitária para que a sigamos e o modo como age para manter-nos nessa norma. No tópico seguinte, partimos às contribuições dos estudos de gênero, das masculinidades e estudos queer como suporte teórico ao que nos propomos.

\section{Sociedades gendradas e corpos educados (à sua própria revelia)}

Ao compreendermos que a narrativa literária é uma forma de entender o mundo, relacionar-se com a própria realidade, dentre outras, concebemos que o corpus literário de qualquer nacionalidade guarda relação com a própria sociedade a que se refere. Assim, voltar a nossa atenção a um texto literário é, em certa medida, observar como este texto dialoga com uma realidade, e não é apenas ficção ou abstração. Em outras palavras, é entender que aquele texto não se refere apenas à ficção, 'inverdades', mas sim, a uma forma de olhar para a realidade que se nos oferece.

Textos como o de Nelson Rodrigues descortinam uma sociedade suburbana carioca machista, sexista, homofóbica, em suma, preconceituosa. Com sua trama, podemos ver um registro dessa sociedade, um registro da nossa realidade, posto que ficam claros aspectos 
sociais, o modo como as identidades são construídas e como a sexualidade de matriz heterossexual é imposta aos indivíduos durante o processo de construção de suas identidades.

Assim, retomamos esses textos e pensamos a problemática do gênero como matriz de organização e hierarquização dos sujeitos sociais e de seus desejos e comportamentos e ainda o modo como surge uma espécie de pedagogia dos corpos que nos ensina quais os lugares sociais que podemos/devemos ocupar a depender de nossa anatomia.

Teresa de Lauretis (1994), em A tecnologia do gênero, reflete sobre o que seja o gênero:

O termo 'gênero' é, na verdade, a representação de uma relação, a relação de pertencer a uma classe, um grupo, uma categoria. Gênero é a representação de uma relação, ou, se me permitirem adiantar-me para a segunda proposição, o gênero constrói uma relação entre uma entidade e outras entidades previamente constituídas como uma classe, uma relação de pertencer; [...] e portanto uma posição vis-à-vis outras classes pré-constituídas. (LAURETIS, 1994, p. 211)

Parafraseando Lauretis (1994), temos que gênero é um jogo que não se joga só. Uma relação entre indivíduos. O indivíduo realiza o seu gênero na relação que mantém com as demais pessoas do seu entorno e performatiza aquilo que o grupo ao qual pertence imagina que deva performatizar. Homem e mulher são artefatos sociais nos quais nos transformamos, que aprendemos a ser e não desdobramentos naturais de nossos sexos biológicos.

Em outras palavras, essa relação de ensino-aprendizagem se dá na ordem dos discursos que produzem os efeitos sobre os corpos e não na imanência de corpos que biologicamente estejam pré-dispostos a agir de dado modo em oposição a outros corpos.

Desse modo, para ser de um grupo é preciso se comportar e reproduzir o que esse grupo comporta como possibilidade de 'masculino' ou de 'feminino' - ou um ou outro, nunca os dois -, na tentativa de pertencer a uma unidade de discursos e de materialidades. São, portanto, relações simbólicas que estabelecemos a partir da ideia binária dos corpos lidos como 'masculinos' e superiores vs. aqueles lidos como 'femininos' e inferiores. Portanto, os discursos partem da morfologia dos corpos - Pênis vs. Vaginas - para determinar comportamentos e hierarquizar sujeitos, dentro de um sistema político e cultural.

Assim, ter um pênis e recusar-se a exercer o 'poder' que este artefato relega ao sujeito é, em certa medida, trair o grupo, a classe a qual se pertence; é recusar-se a 'ser homem'. Logo, 'ser homem', nesse sentido, significa travar relações assimétricas com o outro grupo, o 'ser mulher', a partir de discursos e símbolos que determinem esses lugares sociais, dentre os quais destacamos aqui o casamento como valor cultural que assegura essa assimetria e reitera a heterossexualidade como bem maior dessa sociedade binária e gendrada.

Tratemos, em seguida, em que repousa essa necessidade binária de ler e interpretar o mundo, a partir da leitura dos textos de Adrienne Rich (2003) e de Judith Butler (2015) para compreender melhor como as personagens nelsonrodrigueanas representam o que dissemos.

Apesar de Adrienne Rich ter pensado seu ensaio, Heterossexualidade compulsória e a existência lésbica (2003), a partir da perspectiva da existência lésbica, alguns de seus postulados aplicam-se à existência da homossexualidade masculina, a qual é tema do texto de

Anu. Lit., Florianópolis, v. 25, n. 1, p. 115-129, 2020. ISSNe 2175-7917 
Nelson Rodrigues (1994) em questão.

Para a teórica, há na organização social uma estrutura que retira poderes de escolha das mulheres, impondo-lhes uma única regra de vida, apagando a experiência lésbica ao longo da História, de tal modo que as mulheres se veem obrigadas a cumprir uma agenda que vai desde a romantização das relações heterossexuais, com os contos de fada, até o casamento e o estupro marital, como modo de manter o poder do masculino sobre elas.

The bias of compulsory heterosexuality, through which lesbian experience is perceived on a scale ranging from deviant to abhorrent or simply rendered invisible, could be illustrated from [...] the assumption made by Rossi, that women are "innately" sexually oriented only toward men. ${ }^{1}$ (RICH, 2003, p. 13)

Dada a ressalva de que são experiências distintas, a lésbica e a gay, e apenas compartilham alguns pontos comuns, apropriamo-nos da fala de Rich (2003) para pensar como a existência gay masculina também passa por processo semelhante.

A experiência pela qual passam os homens gays se assemelha na seguinte perspectiva: a sua sexualidade é compulsoriamente orientada para a mulher, deveria ele aceitar e exercer esse lado violento de dominação do feminino de que trata a teórica, caso contrário, seria visto como um ser que rompe com seu destino biológico natural e que deveria ser repreendido e violentado por 'recusar' o lugar privilegiado que a natureza que lhe impôs, algo semelhante ao que já tratamos com o texto de Lauretis (1994).

Numa sociedade em que a experiência feminina é direcionada ao prazer e ao poder masculino, ser homem significa representar um papel de dominação, superior. Onde há um submisso, deve haver um opressor. E negar esse lugar é trair os demais homens, é romper com o grupo.

Em sentido semelhante, Judith Butler (2015) entende ainda que socialmente o sujeito e sua identidade respondem a uma ordem compulsória que alinha sexo/gênero/desejo/prática sexual. E assim, compreensíveis são aqueles sujeitos os quais mantêm certa coerência e continuidade entre essa norma estabelecida. É como uma gramática regendo e impondo os lugares que devemos ocupar.

Conceitua Butler,

[...] os espectros de descontinuidade e incoerência, eles próprios só concebíveis em relação a normas existentes de continuidade e coerência, são constantemente proibidos e produzidos pelas próprias leis que buscam estabelecer linhas causais ou expressivas de ligação entre o sexo biológico, o gênero culturalmente construído e a 'expressão' ou efeito" de ambos na manifestação do desejo sexual por meio da prática sexual. (BUTLER, 2015, p. 43-44).

\footnotetext{
${ }^{1} \mathrm{O}$ viés da heterossexualidade compulsória, através do qual a experiência lésbica é percebida em uma escala que vai de desviante a repugnante ou simplesmente invisível, poderia ser ilustrado a partir [..] [d]a suposição feita por Rossi de que as mulheres são "inatamente" orientadas sexualmente apenas para os homens. (tradução nossa do inglês).
} 
Ou seja, mesmo ao se pensar em uma matriz cultural homossexual, está-se pensando a partir de uma organização heterossexual, tornando-se aquela uma espécie de contracultura à norma, suposta normatividade.

Desse modo, a heterossexualidade compulsória produz o que seja apropriado enquanto normativa social. É o que origina o modo como devemos ser e agir, conforme o gênero em que somos postos ao nascermos. É uma sucessão de discursos naturalizados aos quais o corpo deve assumir e representar na economia heterossexual com fins reprodutivos.

Tais discursos existem para que apenas algumas sexualidades possam aflorar e ter seu desejo legitimado.

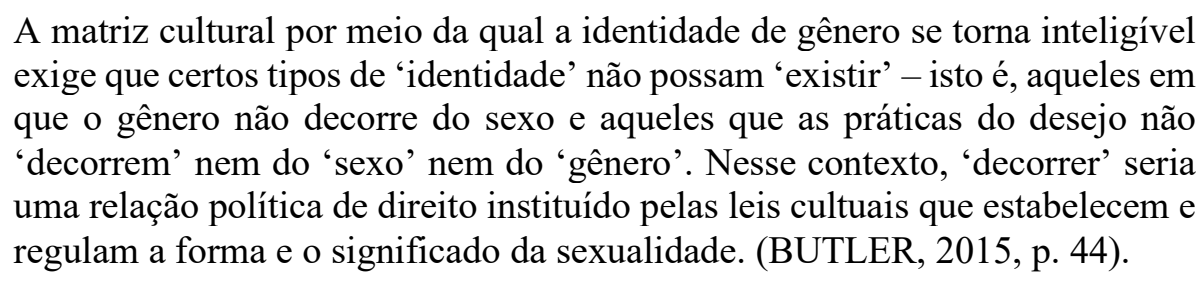

Trata-se, pois de um poder estabelecido que nos compele a reproduzirmos um papel, como em um continuum de cenas teatrais, cujo roteiro não recebemos com antecedência, mas temos introjetado em nossa educação. No texto corpus de nossa análise, por exemplo, temos uma personagem masculina forçada a encenar uma relação heterossexual e um noivado, sem que queira fazê-lo.

Ao expor essa outra realidade, ou possibilidade desviante, a Literatura expõe a própria fraqueza do sistema normativo da sexualidade, ao expor os limites que perturbam essa ordem compulsória. O sujeito homossexual, seu desejo fora da norma e suas atitudes além da heteronormatividade expõem os limites da ordem dominante e passa a ocupar um lugar distinto na sociedade.

Monique Wittig (1992), em La mente hetero, determina que esse lugar destinado à homossexualidade na sociedade deve-se, em grande parte, ao fato de essa mesma sociedade se organizar segundo uma lógica heterossexual, em que outras identidades são apagadas.

Sí, la sociedad hetero se basa en la necesidad de lo diferente/otro a todo nivel. No puede funcionar económica, simbólica, linguística o políticamente sin ese concepto. Esa necesidad de lo diferente/otro es ontológica para todo el conglomerado de ciencias y disciplinas que yo llamo la mente hetero. Pero ¿qué es lo diferente/otro sino lo dominado? Porque la sociedad heterosexual no sólo oprime a lesbianas y homosexuales sino a muchas y muchos diferentes/otras/otros, oprime a todas las mujeres y a muchas clases de hombres, a todas aquellas personas que están en la posición de dominadas. Constituir una diferencia y controlarla es un acto de poder, dado que es esencialmente un acto normativo. Todas las personas tratan de mostrar que la otra o el otro son diferentes. Pero no todas tienen éxito en su empresa. Hay que ocupar una posición social de poder para lograrlo. (WITTIG, 1992, p. 3, 
grifos nossos $)^{2}$

Ou seja, temos uma moral heterossexual a qual repreende e pune o diferente, porém, precisa antes criar a norma para, assim, ter o outro, o diferente, o qual deve ser oprimido. Os corpos que habitamos são, em certa medida, a materialidade desses discursos sociais que nos autorizam ou não a sermos como somos, é a expressão de práticas normativas e normalizadas pelos discursos. Aqueles que não se adéquam ficam à margem, são relegados, excluídos, tornam-se, pois, abjetos.

Existir. Essa é a raiz da questão. Compreender a existência de sexualidades dissonantes, fora do padrão heterossexual compulsório e heteronormativo, é imperativo para a quebra de tabus como o casamento heterossexual.

A partir dos postulados até aqui discutidos, interessa mais do que determinar a sexualidade do protagonista, compreender como o seu comportamento é violentamente reprimido pelo tio (figura masculina) justamente porque tal identidade questiona categorizações hegemônicas de masculinidade.

O conceito de masculinidade hegemônica ganha força nos anos 1980 no seio das discussões dos estudos de gênero e de identidade sexual, consolidando-se como campo de pesquisa acadêmica que passa a questionar a suposta universalidade do sujeito 'homem'.

Simone de Beauvoir já havia conceituado que "não se nasce mulher, torna-se mulher" (2008, p. 5). A partir de sua obra, assim como dos estudos de Kate Millet (2000) e Judith Butler (2015) posteriormente, chegava-se à conclusão de que as mulheres eram mais que apenas os seus corpos e que sua biologia não era seu destino fatal e final. Os estudos de gênero ganham cada vez mais força e suporte teórico. E se não se nasce mulher, tampouco se nasce homem.

É nesse contexto que alguns olhares passam a ser dados para a construção do sujeito masculino. Afinal de contas, a construção social dos gêneros passa a questionar os papeis sexuais antes vistos como "naturais".

O gênero é, nos mais amplos termos, a forma pela qual as capacidades reprodutivas e as diferenças sexuais dos corpos humanos são trazidas para a prática social e tornadas parte do processo histórico. No gênero, a prática social se dirige aos corpos. Através dessa lógica, as masculinidades são corporificadas, sem deixar de ser sociais. Nós vivenciamos as masculinidades (em parte) como certas tensões musculares, posturas, habilidades físicas, formas de nos movimentar, e assim por diante. (CONNELL, 1995, p. 5, grifos nossos).

\footnotetext{
${ }^{2} \mathrm{Sim}$, a sociedade heterossexual baseia-se na necessidade do diferente/outro em todos os níveis. Ela não pode funcionar econômica, simbolicamente, linguisticamente ou politicamente sem esse conceito. Essa necessidade do diferente/ outro é ontológica para todo o conglomerado de ciências e disciplinas que chamo de mente hetero. Mas o que é diferente/outro, senão o dominado? Porque a sociedade heterossexual não apenas oprime lésbicas e homossexuais, mas muitas e muitos diferentes/outras/outros, oprime todas as mulheres e muitos tipos de homens, todos aqueles que estão na posição de dominados. Fazer a diferença e controlá-la é um ato de poder, pois é essencialmente um ato normativo. Todas as pessoas tentam mostrar que a outra ou o outro são diferentes. Mas nem todos são bem-sucedidos em sua empresa. Deve-se ocupar uma posição social de poder para alcançá-lo. (tradução nossa do espanhol).
} 
Sendo, portanto, o gênero uma construção social como indicam Conell (1995) e Butler (2015), ele se molda conforma época e local em que se insere. Assim, não poderíamos pensar em um modo de pertencer a um gênero que fosse único e eterno, mas sim, em sociedades que definem o que é adequado a cada gênero.

Nessa gramática do gênero, quando se trata das masculinidades, rapazes aprendem desde muito cedo a agir distanciando-se daquilo que se convencionou como feminino. Ser homem, nesse sentido, seria ser um corpo, lido como masculino, ou seja, com pênis, com um desejo sexual voltado para corpos opostos, lidos como femininos, com uma prática social dita masculina. $\mathrm{Ou}$, como proporia Butler, seguindo uma ordem compulsória social e não inata.

Os rapazes são pressionados a agir e a sentir dessa forma e a se distanciar do comportamento das mulheres, das garotas e da feminilidade, compreendidas como o oposto. A pressão em favor da conformidade vem das famílias, das escolas, dos grupos de colegas, da mídia e, finalmente, dos empregadores. A maior parte dos rapazes internaliza essa norma social e adota maneiras e interesses masculinos, tendo como custo, frequentemente, a repressão de seus sentimentos. (CONNELL, 1995, p. 6, grifos nossos).

Ainda retomando os estudos de Connell (1995), é importante frisar os diversos espaços da vida social que nos compelem a seguir uma espécie de receita da masculinidade, criando e validando uma só masculinidade. Destaque-se a gradação que vai desde as primeiras relações no âmbito familiar e escolar até as relações empregatícias. Dessa forma, as suas ideias aproximam-se de Rich (2003), quando esta destaca que mulheres lésbicas viam-se forçadas a forjar um comportamento heterossexual e mostrar-se atraente a homens heterossexuais em seus ambientes de trabalhos. Ou seja, as formas de opressão divergem na prática, mas aproximamse nas suas intenções regulatórias.

Os diversos espaços regulatórios que cita Connell (1995), obviamente, determinam a hegemonia daquilo lido como apropriado a cada sexo, assim, certos modos de ser mulher e de ser homem - ou, parafraseando o tio de Eusebiozinho, 'ter jeito de homem' - compõem as bases fundantes do que reconhecemos como masculinidades hegemônicas. Isto posto, parece-nos evidente que se existem masculinidades hegemônicas, existem outras formas de ser homem, outras masculinidades que precisam ser retomadas, respeitadas e legitimadas, como a de Eusebiozinho.

Nesse contexto, portanto, a masculinidade hegemônica não é a única forma de ser homem, porém, é a normativa, é aquela não apenas aceita, como padronizada, mandatária, legitimada. Ela é incorporada na construção da identidade masculina pela constante presença de figuras sociais que reforçam o estereotipo de homem forte, saudável, protetor, agressivo, tudo o que Eusebiozinho, protagonista de "Delicado", não é.

Há uma hegemonia nos modos de ser homem. Ser hegemônico não significa ser violento, na verdade, a violência pode até existir, mas a hegemonia é mais eficaz quando está de tal modo intrínseca à cultura que não nos parece estranha a sua presença. Ou seja, a violência para mantêla não se faz necessária.

Destarte, é imperioso pensar a construção da sexualidade humana em um contexto maior

Anu. Lit., Florianópolis, v. 25, n. 1, p. 115-129, 2020. ISSNe 2175-7917 
que apenas o do desejo sexual, mas sim, como força-motriz da própria identidade como um todo. Quando determinado sujeito é chamado a agir e pensar de certo modo a ele é imposta a maneira 'correta' de se apresentar ao mundo. Tergiversar e ir por um caminho supostamente 'errado' significa sofrer toda sorte de política de adequação.

Cabe-nos ainda questionar quais são as maneiras que a sociedade que cria as normas encontra de fazê-las cumprir. Mais uma vez recorrendo ao texto de Rich (2003), podemos pensar em dois pontos: 1) negar a sexualidade desviante, aquilo que não existe, não necessita representação e 2) o casamento arranjado como forma de correção da sexualidade 'não natural'. Os dois exemplos aplicam-se ao texto literário que lemos aqui, conforme trataremos no tópico seguinte.

\section{A vida de Eusebiozinho como ela não pode ser}

O "Delicado", narrativa curta presente na coleção $A$ vida como ela é..., de Nelson Rodrigues (1994), pode ser lida como um conto-crônica, uma vez que ali se encontram elementos narrativos comuns aos dois gêneros narrativos. Ao deixar a efemeridade das páginas de jornal onde surgiu, a crônica ganha ares literários e passa a interagir com outros gêneros literários, como é o caso do conto. Citando Antonio Candido (1992, p. 21), nessa passagem das crônicas do jornal ao suporte livro, "parecem [que] marcham rumo ao conto". Assim, também lemos as narrativas de $A$ vida como ela é..., uma marcha da crônica rumo ao conto.

A mãe de Eusebiozinho, viúva, cria o filho caçula junto com outras sete filhas. O narrador deixa entrever em diversas passagens que o rapaz tem trejeitos e hábitos considerados femininos. O próprio título da narrativa, irônico, como diversos outros de seu autor, assim como o nome do protagonista, no diminutivo, reforçam a delicadeza do garoto e a forma com que fora criado, a qual será repelida pelo tio.

A masculinidade de Eusebiozinho constrói-se alheia a lugares-comuns daquela hegemônica, a qual se reconhece agressiva, assertiva, com desejo sexual por uma mulher cisgênero $^{3}$. O padrão heteronormativo e heterossexual sustentado pela maioria dos homens em contexto semelhante ao seu - subúrbio carioca - não se encontra na identidade de Eusebiozinho. Em certa medida, ele não se adéqua a esse lugar, o que, a priori, não causa estranhamento naquela família.

Eusebiozinho criou-se agarrado às saias da mãe, das irmãs, das tias, das vizinhas. Desde criança, só gostava de companhias femininas. Qualquer homem infundia-lhe terror. De resto, a mãe e as irmãs o segregavam dos outros meninos. Recomendavam: "Brinca só com meninas, ouviu? Menino diz nomes feios!". O fato é que, num lar que era uma bastilha de mulheres, ele atingiu os dezesseis anos sem ter jamais proferido um nome feio, ou tentado um cigarro. Não se podia desejar maior doçura de modos, ideias, sentimentos. (RODRIGUES, 1994, p. 40).

\footnotetext{
${ }^{3}$ Por cisgênero compreendemos o sujeito que se identifica com o gênero que lhe fora designado ao nascer. Nessa passagem, referimo-nos ao aspecto que valida uma mulher cisgênero como objeto sexual a um homem cisgênero.
} 
O narrador evidencia que o menino fora criado quase que exclusivamente na presença de figuras femininas, proibido de 'dizer nomes feios', uma verdadeira 'doçura de rapaz'. Novamente, é importante pensar a necessidade do narrador, irônico, em deixar claro que Eusebiozinho criara-se longe da masculinidade que seria esperado para esse gênero.

Em segundo lugar, o narrador apresenta dois modelos de masculinidades já nesse pequeno excerto: um hegemônico, aquele a que Eusébio não faz parte; outro paralelo, com uma 'doçura de modos, ideias, sentimentos'. Na sua própria forma de escrever, lê-se uma comparação, assentada em certa ironia própria de seu autor, que nos faz perceber como as identidades sociais e sexuais - são socialmente construídas.

Indubitavelmente, Eusébio representa a construção de uma masculinidade alheia à hegemônica, ou seja, em uma hierarquia de masculinidades, ele ocupa lugar inferior. Poderíamos considerar que há um modo de ser homem, superior, aprendido entre homens, quase uma herança, um segredo compartilhado por eles e restrito ao seu convívio, o qual não chega a Eusébio, dada as suas companhias femininas constantes, segundo o narrador.

Quando se pensa em Butler (2015) e no conceito de heterossexualidade compulsória, podemos voltar ao exemplo do conto-crônica e pensar como, de fato, o texto literário reitera essa postura, da compulsoriedade da heterossexualidade. Alheio à figura masculina que lhe imponha de modo compulsório não apenas a sexualidade padrão, mas igualmente, o comportamento e os trejeitos lidos como apropriados ao gênero masculino, Eusébio tem a sua identidade hierarquicamente posta em um lugar inferior, o lugar não-hegemônico, de nãoprestígio.

Posteriormente, a família é visitada por um tio, ausente até aquele momento. A figura masculina exerce o papel que o pai não pudera exercer e produz-se um choque entre a masculinidade de Eusébio e a do tio. Após um diálogo tenso, a família de mulheres é incumbida de procurar uma namorada para o rapaz.

— Você tem namorada?

- Não.

- Nem teve?

- Nem tive.

Foi o bastante. O velho quase pôs a casa abaixo. Assombrou aquelas mulheres transidas com os vaticínios mais funestos: "Vocês estão querendo ver a caveira do rapaz?". Virou-se para d. Flávia:

- Isso é um crime, ouviu?, é um crime o que vocês estão fazendo com esse rapaz! Vem cá, Eusébio, vem cá! Implacável, submeteu o sobrinho a uma exibição. Apontava:

- Isso é jeito de homem, é? Esse rapaz tem que casar, rápido! (RODRIGUES, 1994, p. 41).

Parafraseando novamente Rich (2003), o casamento arranjado e a orientação sexual voltada para o sexo oposto surgem como formas eficazes de manutenção da hegemonia heterossexual compulsória e normativa. A presença do tio funciona como agente social que controla, vigia e impõe a norma ao sobrinho. A necessidade de casar rápido equivale a dizer que há a necessidade de enquadrá-lo naquilo que o padrão heterossexual determina como 
correto. Em outras palavras, em manter o status quo hegemônico, e salvar Eusebiozinho de uma masculinidade que não seja hegemônica e heterossexual.

Eusebiozinho é exemplo de que o gênero não é construído como expressão ou reflexo de seu sexo natural. Seu corpo assumiu uma série de marcas e reproduz uma série de textos culturais contrários àqueles esperados por seu tio, e pela sociedade de matriz heterossexual. Esse choque no horizonte de expectativa do tio relega o menino a um lugar hierarquicamente inferior, feminino, pois, por não reproduzir uma masculinidade esperada.

Butler (2015), retomando Wittig, afirma que "não há razão para dividir os corpos em sexos masculino e feminino, exceto que uma tal divisão é adequada às necessidades econômicas da heterossexualidade, emprestando um lustro naturalista à instituição" (2015, p. 196). Assim, entendendo-se o corpo como um dado da natureza, o sexo é lido para fins reprodutivos, logo é tão cultural quanto o gênero. E, nessa seara, o casamento é a instituição moral que mantém e intima à manutenção de um padrão heterossexual e heteronormativo em que os gêneros masculino e feminino assumem e desempenham uma função social.

Em outras palavras, a necessidade de Eusébio ser casado, ainda que a sua revelia, representa a obrigação do menino em representar uma masculinidade aceita e incentivada, cultural. E o tio, conforme já indicamos, assume o 'papel de homem' em convívio com essa masculinidade hegemônica que deve passá-la adiante.

Ainda que o narrador não careça chamar de feminino, o modo como apresenta Eusébio deixa isso claro aos leitores. Aliado a isso, os subtítulos elucidam essas características do menino. O trecho de onde a passagem anterior da obra fora retirada chama-se 'flor de rapaz'. A partir desse trecho, há o começo de uma verdadeira caça à esposa ideal ao garoto.

E começou o idílio mais estranho de que há memória. Numa sala ampla da Tijuca, os dois namoravam. Mas jamais os dois ficaram sozinhos. De dez a quinze mulheres formavam a seleta e ávida assistência do romance. Eusebiozinho, estatelado numa inibição mortal e materialmente incapaz de segurar na mão de Iracema. Esta, por sua vez, era outra constrangida. Quem deu remédio à situação, ainda uma vez, foi o inconveniente e destemperado tio. Viu o pessoal feminino controlando o namoro. Explodiu: "Vocês acham que alguém pode namorar com uma assistência de Fla-Flu? Vamos deixar os dois sozinhos, ora bolas!". Ocorreu, então, o seguinte: sozinha com o namorado, Iracema atirou-lhe um beijo no pescoço. O desgraçado crispou-se, eletrizado:

— Não faz assim que eu sinto cócegas! (RODRIGUES, 1995, p. 42).

Novamente é a presença masculina que surge para propiciar o namoro entre Eusébio e Iracema. O tio está sempre encarregado de administrar os passos rumo à masculinidade hegemônica que espera do sobrinho. Na sequência, os preparativos para o casamento são pensados por Eusebiozinho que escolhe e ajuda na confecção do vestido de noiva.

Posteriormente a esse momento, os preparativos correm a contento, até que o vestido de noiva some, e após longas buscas, a narrativa chega ao fim bem ao gosto nelsorodrigueano.

Uns quatro dias antes do casamento, o vestido estava pronto. Meditativo, 
Eusebiozinho suspirava: “A coisa mais bonita do mundo é uma noiva!”. Muito bem.

Passa-se mais um dia. E, súbito, há naquela casa o alarme: "Desapareceu o vestido da noiva!". Foi um tumulto de mulheres. Puseram a casa de pernas para o ar, e nada. Era óbvia a conclusão: alguém roubou! E como faltavam poucos dias para o casamento sugeriram à desesperada Iracema: "O golpe é casar sem vestido de noiva!". Para quê?

Ela se insultou:

- Casar sem vestido de noiva, uma pinóia! Pois sim!

Chamaram até a polícia. O mistério era a verdade, alucinante: quem poderia ter interesse num vestido de noiva? Todas as investigações resultaram inúteis. E só descobriram o ladrão quando dois dias depois, pela manhã, d. Flávia acorda e dá com aquele vulto branco, suspenso no corredor. Vestido de noiva, com véu e grinalda - enforcara-se Eusebiozinho, deixando o seguinte e doloroso bilhete: "Quero ser enterrado assim". (RODRIGUES, 1994, p. 43).

As perguntas são várias: Até que ponto há um padrão de masculino e um de feminino? Como o gênero alheio ao que se espera como representação de um sexo é combatido socialmente? De que modo a sociedade - representada pelo tio - age para padronizar os corpos e as relações humanas? Como um processo normatizador pode produzir tanto sofrimento psíquico que culmine no suicídio de um indivíduo?

A homossexualidade sugerida do rapaz e o modo como deve ser combatida pelo tio, com o casamento às pressas, reforçam a hierarquização das masculinidades. A de Eusébio é menor que a do tio, uma vez que ele não tem o seu desejo sexual voltado ao sexo oposto, tampouco assume marcas do gênero masculino no seu comportamento, gostos e gestos.

Em uma sociedade gendrada, coube ao tio por o sobrinho na norma, forçá-lo a reproduzir comportamentos e manter relações sociais que reiterassem a representação de uma masculinidade discursiva, política e social numa relação de pertencimento a uma classe, levando-o a assumir atributos e sustentar um comportamento social e cultural.

Eusebiozinho não nega nem reage - será que teria como fazê-lo? - à imposição do tio. Antes, cede, mas não consegue representá-la. Metaforicamente, o garoto recebe o convite ao clube do qual faz parte o tio, mas não sabe como fazer parte desse clube, não sabe existir nesse espaço e sucumbe, morre.

A morte é o caminho final a Eusébio, assim como fatalmente o é a quem foge à norma. Uma vez negada a sua existência enquanto homem que não assume as expectativas do gênero masculino caberia ao protagonista duas mortes: 1) simbólica e individual ao assumir uma identidade mais hegemônica, ou 2) coletiva, ao assumir-se como é e vê-se como um pária social. Ou Eusébio 'mata' quem é para ser aceito, assumindo uma identidade que não é a sua ou morre por ser como é.

Pensando em possibilidades de respostas aos questionamentos aqui propostos, o padrão de masculinidade hegemônica imposta a Eusebiozinho é um fardo maior do que ele poderia suportar, o que o leva ao suicídio, por não conseguir perfomartizar uma identidade e sexualidade esperada pelo tio - sociedade - e lida como correta, adequada e, por fim, normal.

Em uma sociedade em que as sexualidades dissidentes são violentadas a se converterem 
a uma norma discursiva e onde a masculinidade se apresenta como norma heterossexual, compulsória e violenta, o final trágico é a morte como mecanismo de higienização social ${ }^{4}$, ou seja, para 'limpá-la' daqueles corpos abjetos, ainda que não sejam necessariamente gays, mas por assumir uma masculinidade contrária à hegemônica.

\section{Referências}

BEAUVOIR, Simone de. O segundo sexo. Lisboa: Bertrand, 2008. 2. v.

BUTLER, Judith. Problemas de gênero - feminismo e subversão da identidade. Trad. de Renato Aguiar. 8 ed. Rio de Janeiro: Civilização Brasileira, 2015.

CANDIDO, Antonio. A vida ao rés do chão. In: CANDIDO, Antonio et al. A crônica: o gênero, sua fixação e suas transformações no Brasil. Campinas: Editora da UNICAMP; Rio de Janeiro: Casa de Rui Barbosa, 1992, p. 13-22.

CONNELL, Robert. Políticas da masculinidade. Educação e Realidade, Porto Alegre, v. 20, n. $2,1995$.

FOUCAULT, Michel. Os anormais. Trad. de Eduardo Brandão. São Paulo: Martins Fontes, 2001.

LAURETIS, Teresa de. A tecnologia do gênero. Trad. de Susana Bornéo Funck. In: HOLLANDA, Heloísa Buarque de (Org.). Tendências e impasses: o feminismo como crítica da cultura. Rio de Janeiro: Rocco, 1994, p. 206-242.

MILLET, Kate. Sexual politics. Chicago: University of Illinois Press, 2000.

RICH, Adrienne Cecile. Compulsory Heterosexuality and Lesbian Existence. Journal of Women's History, v. 15, n. 3, p. 11-48, 2003.

RODRIGUES, Nelson. A vida como ela é.... São Paulo: Companhia das Letras, 1994.

RODRIGUES, Nelson. O beijo no asfalto. Rio de Janeiro: Nova Fronteira, 2004.

WITTIG, Monique. La mente hetero. Discurso leído por la autora en Nueva York durante el Congreso Internacional sobre el Lenguaje Moderno realizado en 1978 y dedicado a las lesbianas de EE.UU. Boston: Beacon, 1992.

\section{NOTAS DE AUTORIA}

Paulo Valente (professorpaulovalente@gmail.com) é doutorando em Literatura na UFSC, na linha de pesquisa Crítica feminista e Estudo de Gênero. Foi professor de Literatura e Teoria Literária da Universidade Federal do Pará e Universidade do Estado do Pará. Mestre em Letras - Estudos Literários (UFPA/UERJ, 2012), Graduado em Letras - Língua Portuguesa (UFPA, 2010) e Graduado em Comunicação Social - Jornalismo (UNAMA, 2009).

\section{Como citar esse artigo de acordo com as normas da revista}

\footnotetext{
${ }^{4}$ Final semelhante ao de Arandir, do clássico $O$ beijo no asfalto, cujo trecho abre esse trabalho.
} 
VALENTE, Paulo. A morte como higienização social/sexual na obra de Nelson Rodrigues: uma leitura de gênero, sexualidade e masculinidades. Anuário de Literatura, Florianópolis, v. 25, n. 1, p. 115-129, 2020.

\section{Contribuição de autoria}

Não se aplica.

\section{Financiamento}

O presente trabalho foi realizado com apoio da Coordenação de Aperfeiçoamento de Pessoal de Nível Superior - Brasil (CAPES) - Código de Financiamento 001.

\section{Consentimento de uso de imagem}

Não se aplica.

\section{Aprovação de comitê de ética em pesquisa}

Não se aplica.

\section{Licença de uso}

Este artigo está licenciado sob a Licença Creative Commons CC-BY. Com essa licença você pode compartilhar, adaptar, criar para qualquer fim, desde que atribua a autoria da obra.

\section{Histórico}

Recebido em: 14/01/2020

Aprovado em: 06/05/2020 